\title{
A RENOVAÇÃO PECEBISTA NOS ANOS 50: UM PROJETO INSPIRADO NA IDEOLOGIA GRAMSCIANA
}

THE BRAZILIAN COMMUNIST PARTY (PCB) RENEWAL IN THE 1950S: A PROJECT INSPIRED BY THE GRAMSCINIAN IDEOLOGY

Laura de Oliveira Assis ${ }^{1}$

Leandro Pereira Gonçalves ${ }^{2}$

\section{RESUMO}

O artigo analisa a mudança ideológica pela qual passou o Partido Comunista Brasileiro - PCB - na década de 1950. Mostra a forte influência de Antônio Gramsci no projeto político pecebista após o XX Congresso do Partido Comunista da União Soviética - PCUS - e sua relação com os acontecimentos de 1964. Identifica quais foram os principais erros da esquerda, que no momento do golpe manteve-se paralisada, impedida pela nova orientação ideológica mais democrática e favorável as legalidades constitucionais, de uma ação mais combativa e até mesmo golpista. O PCB, que no início da década de 60 participou ativamente dos movimentos populares contra as forças reacionárias, não foi capaz de articular devidamente a classe operária e demais trabalhadores em direção a uma conscientização política. A esquerda mais uma vez foi impedida de realizar seu tão sonhado projeto socialista. Toda uma geração de militantes sofreria as agruras da prisão, do exílio e do esquecimento.

PALAVRAS-CHAVE: PCB; XX Congresso do PCUS; Gramsci; Mudança.

\section{ABSTRACT}

The research examines the ideological shift by which passed the Brazilian Communist Party - PCBs - in the 1950s. Shows the strong influence of Antonio Gramsci in the political project after the XX pecebista Congress of the Communist Party of the Soviet Union - PCUS - and its relation to the events of 1964. Identifies what were the biggest mistakes of the Left, which at the time of the coup has remained paralyzed, prevented by the new ideological direction more favorable to democratic and constitutional legalities of an action and even 
more combative coup. The PCBs, which at the beginning of the 60 s took an active part of the popular movement against the reactionary forces, was unable to properly articulate the working class and other workers toward a political awareness. The left has once again been prevented from achieving its dream project as socialist. A whole generation of militants from prison suffer the bitterness of exile and oblivion.

KEYWORDS: PCB; XX Congress of the Communist Party of the Soviet Union; Gramsci; Change.

\section{INTRODUÇÃO}

Fundado em 1922, o Partido Comunista do Brasil (PCB) teve sua trajetória marcada pela luta em defesa da classe operária. Passou por muitas crises, sendo a causada pelo XX Congresso do Partido Comunista da União Soviética (PCUS) a que mais ficou registrada em sua história. Sua aproximação com a União Soviética foi determinante para que em 1956, com a abertura dos arquivos secretos de Stalin pelo secretário-geral do partido soviético Nikita Kruchev, o PCB experimentasse um longo período de silêncio e autocríticas. O silêncio só foi quebrado com o início das discussões e dos debates veiculados na imprensa comunista, evidenciando um árduo processo de superação do marxismo-leninismo dogmatizado.

A mudança na política comunista nos anos 50 teve seu ápice modernizante concluído com a Declaração de Março de 1958. Esta representou o início de uma nova fase na vida do partido, defendendo o movimento democrático-nacionalista e a política de frente única na luta pelo socialismo. Os movimentos revolucionários cederam lugar ao caminho pacífico, numa clara aproximação com o teórico marxista Antônio Gramsci, que ficou conhecido pelos comunistas brasileiros através de escritos do Partido Comunista Italiano.

Este ensaio tem como objetivo analisar esse conturbado processo de mudança ideológica ocorrido na década de 50, com suas influências e 
conseqüências no meio trabalhista. Mostrar a marca da política gramsciana presente no novo projeto pecebista, pois ao contrário de que comumente costuma-se pensar, a grande virada do PCB, rompendo com o stalinismo e outros dogmas não se deu sem uma longa e violenta luta interna. Este trabalho apresenta a interessante maneira como o PCB avança nos momentos de crise ideológica, modificando-se e absorvendo o pensamento mais atualizado, ajeitando e controlando a estrutura partidária.

O primeiro capítulo apresenta uma breve história do PCB, desde sua fundação em 1922 até a amarga derrota sofrida com o golpe de 1964; o segundo capítulo trabalha a nova política adotada e sua relação com as teorias de Gramsci; o terceiro e último capítulo mostra a prática do novo projeto, a política de aliança, a luta democrática etc. Para a pesquisa foram utilizadas fontes bibliográficas e documentais específicas.

O período estudado - 1950 a 1964 - abrangeu muitos pontos importantes da história do PCB, como a realização do VI Congresso, considerado como a superação da fase imatura, os debates sobre o stalinismo ponto chave da pesquisa e o ponto central do processo que se deu com a elaboração da chamada nova política em 1958.

1 BREVE HISTÓRIA DO PCB: DA FUNDAÇÃO À MUDANÇA IDEOLÓGICA NA DÉCADA DE 50

Nas primeiras décadas do século $\mathrm{XX}$, o panorama nacional foi marcado por intensas modificações de ordem política, econômica e social em função do desenvolvimento industrial, o qual foi garantido em boa parte pelo crescimento da economia cafeeira e pelo afluxo do capital internacional.

À medida que a indústria foi sendo consolidada, duas novas classes sociais possuidoras de interesses antagônicos passaram a dominar o cenário no país. De um lado a burguesia, representada pelos industriais, banqueiros, comerciantes, etc., detentora dos meios de produção; do outro o proletariado, constituído pelos trabalhadores fabris e do comércio, expropriados de 
quaisquer meios de produção, dispondo apenas de sua força de trabalho, a qual se vêem obrigados a vender para o burguês.

Ao passo que a economia foi se desenvolvendo, com o conseqüente aumento das indústrias e do operariado, começaram a surgir organizações operárias em luta por aumentos salariais e melhores condições de trabalho, sendo a greve a principal arma utilizada pelos trabalhadores. Tais organizações lideradas pelo movimento anarco-sindicalista defendiam a ação direta como forma de destruir o capitalismo e implantar a autogestão social, ignorando qualquer tipo de partidarismo. A necessidade de superar o projeto anarquista aliado às repercussões da Revolução Russa no Brasil contribuiu para o surgimento dos primeiros grupos comunistas.

Foi nesse contexto de lutas sociais que, em março de 1922, fundouse o Partido Comunista do Brasil (PCB), resultado das transformações na sociedade e reflexos dos acontecimentos de 1917 na Rússia. O partido nasce enquanto seção brasileira da Internacional Comunista $(\mathrm{IC})^{3}$, mas só foi aceito como membro dessa em 1924, depois que um relatório de suas atividades foi elaborado e enviado a Moscou. Apesar de membro da III Internacional, as relações do PCB com a mesma serão pouco estreitas, situação que permanece ate fins de 1928, ou seja, em seus primeiros anos de existência o PCB gozou de certa autonomia com relação à União Soviética. A sujeição do partido a Internacional Comunista deve ser entendida em função das carências teóricas e políticas dos comunistas brasileiros.

A estratégia política foi definida no artigo $2^{\circ}$ de seu Estatuto aprovado no Congresso de Fundação:

O PCB tem o objetivo de atuar como organização política do proletariado e também lutar e agir pela compreensão mútua internacional dos trabalhadores. O partido da classe operaria é organizado com o objetivo de conquistar o poder político pelo proletariado e pela transformação política e econômica da sociedade da sociedade capitalista em comunista (MOVIMENTO COMUNISTA, 1922 apud SEGATTO, 1981, p. 20).

Poucos meses após sua fundação, mais precisamente em julho de 1922, o PCB foi jogado na ilegalidade, devido à decretação do estado de sítio, 
após o Levante do Forte de Copacabana ${ }^{4}$, assim permanecendo até 1927. Ao término do governo de Artur Bernardes, com o fim do estado de sítio, a vida política foi normalizada e o partido passou por um novo e curto período de legalidade interrompido nesse mesmo ano pela Lei Celerada ${ }^{5}$.

Em seus primeiros anos de vida, o PCB travou uma incansável luta político ideológica com o anarquismo, que ainda representava forte influência no movimento operário. Foi também durante esse período que Astrojildo Pereira, membro-fundador do partido, estabeleceu contato com Luis Carlos Prestes, líder da Coluna e figura de grande expressão popular, mas tal aliança não chegou a se efetivar, pelo menos naquele momento.

\begin{abstract}
No ano de 1928, o PCB já possuía uma estrutura interna bem consolidada, com alguma influência no movimento operário sendo internacionalmente reconhecido. Apesar das fragilidades teóricoideológicas e políticas, foi capaz de participar e intervir ativamente em, praticamente, todos os níveis e elaborar uma linha política nacional-popular. "De alguns poucos militantes quando de sua fundação, contava, em 1928, com aproximadamente 1200 membros." (SEGATTO, 1981, p. 30).
\end{abstract}

Em fins de 1928, início de 1929, aconteceu o III Congresso do PCB, cuja pauta discutida foi a luta contra o imperialismo e a situação nacional. As teses aprovadas passaram a definir a economia brasileira como agrária semifeudal e semi-colonial. Além do III Congresso do PCB, o ano de 1929 foi marcado pela efervescência política. A diversidade de forças que se aglutinou em torno da Aliança Liberal fazia oposição sistemática a oligarquia e ao então presidente Washington Luis. A coligação partidária oposicionista lançou a candidatura de Getúlio Vargas à presidência da república, mas nas eleições realizadas em março de 1930 o candidato aliancista foi derrotado, o que fez originar um ambiente conturbado liderado pelos tenentes e grupos de políticos civis, os "tenentes civis" apoiando um golpe que eclodiu em outubro e no dia 3 de novembro, Vargas assumiu a chefia do governo provisório da nação.

Durante esse período o PCB passou por profundas mudanças internas que não foram apenas de linha política, mas também de organização. Influenciado pela tática preconizada pelo VI Congresso da IC, o PCB adotou 
uma nova política baseada em dois pontos: rompimento definitivo da política frentista e proletarização do partido.

A política de frente ampla foi considerada direitista, o obreirismo marcou a substituição dos antigos dirigentes, considerados pequenos burgueses por operários, que nem sempre estavam preparados politicamente e possuíam grandes debilidades ideológicas. Tal orientação foi uma catástrofe, o período da proletarização estendeu-se ate meados de 1933. Como conseqüência da vulgarização, da esquematização e dogmatização do marxismo, o PCB sofreu uma desarticulação que o levou ao isolamento e a omissão no período dos acontecimentos de 1930.

Apesar de certo crescimento político no movimento operário nacional, o partido comunista no início da década de 30 teve suas ações revolucionárias bastante limitadas pela incorporação mecânica das teses do VI Congresso da IC, que acabaram levando-o a uma proposta dogmática, não condizente com a realidade histórica brasileira. Também no período da proletarização, o PCB não obedeceu às ordens da Internacional com relação ao pedido de Prestes de ingresso ao partido. Os comunistas brasileiros 0 atacavam chamando-o de caudilho pequeno-burguês. Prestes só foi aceito em agosto de 1934 por ordens expressas de Moscou.

$\mathrm{Na}$ época da admissão de Luis Carlos Prestes no PCB, a realidade do Brasil estava voltada para a articulação de uma frente única antifascistaantiintegralista ${ }^{6}$. A ascensão do nazismo na Alemanha e o avanço do fascismo no mundo levou o Komintern a repensar a questão das frentes democráticas, consideradas pelo VI Congresso da Internacional como desvios direitistas.

No ano de 1935, a tática da frente popular contra o fascismo foi adotada pelo VII Congresso do PCUS e aplicada ao Brasil pelo PCB, que no mesmo ano deu origem a Aliança Nacional Libertadora ( $\mathrm{ANL}$ ), com o intuito de se opor ao fascismo e ao integralismo. A ANL foi lançada oficialmente em 30 de março de 1935 no Rio de Janeiro e na ocasião Prestes foi aclamado presidente de honra. Em sua primeira fase de existência, a ANL organizou um amplo movimento de massa, alcançando uma dimensão inédita na história do Brasil. Participaram do movimento: comunistas, socialistas, liberais, operários, integrantes da classe média e etc. 
O programa defendido pela ANL estampou a diversidade de interesses políticos, sociais e econômicos, reflexo dos diferentes grupos sociais que a compunham. Suas propostas e reivindicações foram expressas no Manifesto-Programa Nacional Libertador de fevereiro de 1935:

\begin{abstract}
Cancelamento das dividas imperialistas, nacionalização das empresas imperialistas, liberdade em toda a sua plenitude, direito do povo manifestar-se livremente, entrega dos latifúndios ao povo laborioso que o cultiva a libertação de todas as camadas camponesas da exploração dos tributos feudais pagos pelo aforamento, pelo arrendamento da terra, etc.; a anulação total das dividas agrícolas, a defesa da pequena e media propriedade contra a agiotagem, contra qualquer execução hipotecaria diminuição dos impostos a classes laboriosas; aumento de salários; assistência ao trabalhador e instrução (PROGRAMA NACIONAL LIBERTADOR, 1935 apud SEGATTO, 1981, p. 40).
\end{abstract}

A adesão da ANL pelo PCB representou, mesmo que timidamente a adoção da política de frente popular contra o fascismo e, mais especificadamente no caso do Brasil, contra o integralismo. Definida em 1935, no VII Congresso da Internacional Comunista, a política de frente popular, passou a constituir uma diretriz a ser seguida por todos os partidos comunistas. O crescimento da ANL assumiu grandes proporções, confirmada pelo número de participantes, que só no Distrito Federal chegou a 50.000 inscritos.

Em julho de 1935, a organização, ANL, foi jogada na ilegalidade pelo governo Vargas, que usou como pretexto para o fechamento o discurso que Prestes fez no dia 5 de julho, depois de uma longa estada na URSS. O governo considerou subversivo o discurso, perturbador da ordem política e social. $\mathrm{Na}$ ilegalidade e tendo a frente os comunistas, a ANL começou a organizar uma insurreição, através dos quartéis. Ela não demorou muito para acontecer, mas não obteve sucessos, já que os movimentos aconteceram isoladamente e sem grandes adesões, terminando em completo fracasso e derrota.

A partir desse momento os setores progressistas e claro o PCB passaram a sofrer violenta repressão, com grande número de prisões, assassinatos e muita gente sendo exilada. Nesse momento foram criadas as polícias especiais e o Departamento de Ordem Política e Social (DOPS), toda e qualquer oposição ao governo era rapidamente eliminada. $\mathrm{O}$ caminho abriu-se 
para a instauração de um regime de ditadura aberta em 1937, Getúlio Vargas dá início ao Estado Novo (SEGATTO, 1981, p. 43).

A Intentona Comunista representou a última manifestação da rebeldia tenentista, comprovada pela maioria de militares e pela tradição golpista nas lutas desde 1922. Como reflexo dos movimentos de 35, a atuação política pecebista tornou-se praticamente inexistente. O PCB não deixou de existir, mas não houve nenhum foco de agitação, já que grande parte dos militantes comunistas encontravam-se presos, situação que só começou a se modificar em 1942.

Os anos 40 iniciam-se com um paradoxo: período marcado pela $2^{2}$ Guerra Mundial, o Brasil entra no conflito ao lado dos aliados (União Soviética, EUA, Inglaterra) contra o nazi-fascismo, porém, a situação interna do país quanto ao regime político adotado assemelhava-se à ditadura fascista, provocando um amplo movimento de oposição ao Estado Novo. Esse foi um novo momento para a reorganização do PCB, uma nova chance de luta pelas liberdades democráticas.

O PCB mais uma vez passou a influenciar a vida política brasileira, experimentando um novo crescimento com base na luta contra o fascismo e também contra o Estado Novo, aproveitando o clima para promover uma aproximação do Brasil com a URSS. A movimentação democrática, da qual participou o PCB, ocasionou de certa forma, uma revisão no governo de Getúlio Vargas, no sentido de que se realizassem nas instituições políticas brasileiras uma redemocratização. No dia 28 de fevereiro, o governo decretou 0 Ato Adicional $\mathrm{n} \cong 9$, que fixou prazo de noventa dias para a marcação de eleições presidenciais.

As respostas às pretensões exibidas nos primeiros anos de 1940, chegaram em 1945, com o fim do Estado Novo, a derrota dos regimes nazifascistas na Europa, a anistia para presos políticos comunistas, inclusive Prestes, preso desde a Intentona em 1935 e o PCB de volta a legalidade.

As novas condições históricas fizeram com que o governo estadonovista chegasse ao fim com um golpe comandado por Dutra e Góes Monteiro, apoiados pelas forças conservadoras. Mas o clima do pós-guerra garantiu as eleições que estavam marcadas. O PCB se preparou para as eleições do dia 2 de dezembro, na qual foram lançados candidatos em quase 
todo o país com esquema de grande agitação e propaganda. $O$ desempenho alcançado pelo PCB nas eleições foi surpreendente, Yeddo Fiúza que pleiteou o cargo à presidência da república obteve cerca de $10 \%$ do número total de votos. Além disso, Prestes foi eleito senador pelo Distrito Federal e outros 14 deputados foram eleitos (MORAES; VIANA, 1982, p. 112).

O quadro político internacional de 1947 foi alterado, o início da Guerra Fria mostrou ao mundo muito mais que duas formas de se organizar a economia. Estados Unidos e União Soviética protagonizaram uma divisão ideológica que alcançou a esfera mundial, onde duas escolhas eram possíveis: ou se defendia o capitalismo ao lado dos EUA, ou aliava-se ao bloco socialista liderado pela URSS. Tais mudanças na situação internacional já haviam sido prenunciadas em 1946, quando Winston Churchill, em um discurso feito em Fulton, EUA, fez uso da expressão "Cortina de ferro" para se referir a separação entre paises capitalistas e paises socialistas.

Os efeitos da Guerra Fria tiveram grande repercussão no Brasil, provocando uma intensa campanha contra o PCB. Em 1946, documentos confidenciais já davam conta que o ministério estava à eminência de fechar 0 partido, mas pesava o fato de a conjuntura internacional não ser favorável já que na época não havia como serem desfeitas as alianças do tempo de guerra, quando os partidos comunistas e a União Soviética foram considerados aliados na luta contra o fascismo (SILVA; SANTANA, 2007, p. 116).

Paralelamente a esses acontecimentos, pesou sobre o PCB uma denúncia feita ao Tribunal Eleitoral, acusando-o de ter dois estatutos, de se denominar Partido Comunista do Brasil e não Brasileiro e de utilizar-se de símbolos internacionais (martelo e foice). Em conseqüência disso e de uma série de outros motivos, no dia 7 de maio de 1947, o registro do PCB foi cassado (SEGATTO, 1981, p. 58).

O período em que o PCB ficou na ilegalidade trouxe como conseqüência uma revisão radical, que nos anos que se seguiram provocou uma metamorfose no partido. A nova linha política começou a ser traçada com o Manifesto de Janeiro em 1948 e teria sua elaboração mais acabada com o Manifesto de Agosto de 1950.

O Manifesto de Janeiro procurou de início fazer uma autocrítica da política empregada no período anterior que, segundo o Manifesto, caracterizou- 
se como uma política de aliança com a burguesia-progressista e pela pouca atenção às lutas dos trabalhadores rurais que seriam os grandes aliados do proletariado. Vale lembrar que o processo de mudança no PCB também foi influenciado pela transformação no movimento comunista mundial.

O Manifesto de Agosto reelaborou de forma mais radical o Manifesto de Janeiro e trouxe uma nova forma de organização da luta, a Frente Democrática de Libertação Nacional, que recrutaria militantes nos mais diversos meios. Apesar das mudanças, a concepção do partido em relação à realidade brasileira continuou deturpada, persistindo a mesma política sectária.

A linha política do Manifesto de Agosto continuava orientando o PCB e no ano de 1954, o país foi surpreendido com a notícia do suicídio de Vargas e com ela uma onda de simpatia ao ex-presidente envolveu o país. O partido não escapou a indignação popular. No mesmo dia do suicídio, o jornal do PCB, A Imprensa Popular trouxe a seguinte manchete: "Abaixo o governo de traição nacional de Vargas" (SEGATTO, 1981, p. 69). E mais uma vez partiu para uma revisão de sua posição política.

Entre 7 e 11 de novembro de 1954, foi realizado o IV Congresso do PCB. Nele seriam definidas as etapas da revolução brasileira, bem como as forças que dela participariam. O informe aprovado assegura:

Lutamos pela destruição do atual regime dominante no Brasil. Sem destruir as bases do atual regime de libertar o Brasil do tubo imperialista livrar as massas trabalhadoras da exploração crescente e garantir o desenvolvimento independente da economia nacional. $O$ atual governo defende pela forca os privilégios dos latifundiários e grandes capitalistas ligados aos imperialistas norte-americanos por ser um país semicolonial e semifeudal, as atuais relações de produção no Brasil opõem-se violentamente ao desenvolvimento das forcas produtivas. As classes moribundas impedem o livre curso da lei da correspondência obrigatória entre as relações de produção e o caráter das forcas produtivas. É necessário forjar a forca social capaz de vencer a resistência que a minoria reacionária oferece ao progresso do Brasil (PRESTES, 1954 apud SEGATTO, 1981, p. 7172).

O programa aprovado no IV Congresso representou para seus idealizadores um evento de suma importância, no qual o partido pretendia dar um salto de qualidade, deixando a juventude para entrar no período de 
amadurecimento político partidário. O último ponto do programa definiu a questão da Frente Democrática de Libertação Nacional, uma aliança das forças fundamentais operário-camponesas com setores da pequena burguesia urbana, na qual parte dos grandes industriais e comerciantes, afetados com a concorrência dos imperialistas norte-americanos, reunir-se-iam.

O IV Congresso do PCB realizou-se segundo critérios pouco democráticos, não apresentou ao partido grandes alterações em sua linha política, ao contrário, apenas ratificou concepções básicas do Manifesto de Agosto de 1950. Mas diante da crise em que o partido se viu, após a morte de Getúlio Vargas, evidenciou-se que as coisas não poderiam continuar do jeito que estavam. O período seguinte exigiu uma nova proposta política, não tanto pelo suicídio de Vargas, mas pela crise trazida ao meio comunista pelo XX Congresso do Partido Comunista da URSS. Observa-se claramente que a partir das mobilizações antigolpistas verificadas após o suicídio de Vargas, os pecebistas passaram a valorizar as liberdades democráticas, analisando de forma mais objetiva a conjuntura da realidade brasileira. Após o IV Congresso, - PCB procurou impedir qualquer ação que facilitasse um golpe do inimigo e empenhou-se na campanha de Juscelino Kubistshek, em 1955, abandonando na prática a política do enfrentamento de tempos passados (SILVA; SANTANA, 2007, p. 122).

Juscelino Kubistshek foi eleito presidente. O período exigiu que as questões democráticas fossem colocadas em pauta, devido à inserção das massas populares no processo político. A época foi marcada pelo desenvolvimento econômico e capitalista.

No XX Congresso do PCUS em fevereiro de 1956, Nikita Khuchtchev denunciou os crimes de Stalin, a ditadura e o "culto à personalidade". Pouco tempo depois, o mundo comunista se viu em uma grande confusão.

No Brasil, os pecebistas ficaram perplexos com as revelações, chegando até mesmo a duvidar de sua veracidade, pensando que tudo se tratava de uma intriga provocada por anticomunistas. Anos na defesa e no estudo do marxismo-leninismo fizeram com que militantes e partidos comunistas do mundo inteiro desacreditassem nos crimes denunciados pelo secretário-geral do PCUS. As incertezas e as dúvidas só foram deixadas de 
lado, quando Diógenes Arruda, representante do PCB no XX Congresso retornou e confirmou as denúncias contra Stálin. Após um longo período de silêncio entre os dirigentes do partido, o Comitê Central lançou, em outubro de 1956, o documento "Projeto de Resolução sobre o XX Congresso" como tentativa de abrir os debates e controlá-los de forma mais amena (SANTOS, 2003, p. 236).

A imprensa pecebista, que às vésperas do $X X$ Congresso, mantinha em suas páginas uma expectativa otimista com relação ao partido, após a abertura dos arquivos de Stálin passou por um processo de reflexão. As notícias sobre as temáticas levantadas por Kruchev chegavam de todas as partes, como exemplo pode citar-se o Partido Comunista Italiano, que foi um estimulo para que o PCB saísse da passividade em que se encontrava.

Voltando ao Projeto de Resolução sobre o XX Congresso, nesse documento o partido (PCB) reconheceu a falta de democracia interna, o excessivo centralismo, a arrogância e a auto-suficiência dos dirigentes. Criticou também o mandonismo de cima para baixo, o dogmatismo que permeou por muitos anos a política do PCB, reconheceu a passividade de aceitação das idéias de comunistas e de partidos comunistas de outros paises sem espírito analítico.

À medida que os debates se intensificavam, divergências e conflitos foram tomando corpo no seio do PCB, duas correntes se formaram no interior do partido. Uma delas defendia a promoção de uma autocrítica substancial e reconhecia a necessidade de uma reflexão nova em torno da questão democrática; já a outra objetivava o encerramento dos debates comprometidos com o passado e era resistente a qualquer autocrítica mais profunda.

Prevaleceu a corrente de pensamento disposta a promover uma autocrítica no interior do partido. Já no início de 1958 surgem os primeiros frutos dos debates provocados pelo XX Congresso do PCUS, que se manifestaram na "Declaração de Março" e num texto de Luis Carlos Prestes, em que o PCB faz sua autocrítica e começa a esboçar uma política diferente daquela seguida anteriormente. O Comitê Central aprovou uma política que salientava o desenvolvimento do capitalismo no processo histórico brasileiro, favorecendo a luta pela democracia, reconhecendo que a revolução no Brasil 
não seria ainda socialista, mas antiimperialista e antifeudal, nacional e democrática.

Os pontos mais importantes sobre a Declaração de Março são: a implantação de um regime nacional democrático, através do caminho pacífico e o desenvolvimento da Frente Única Nacionalista e Democrática. Prestes, alguns dias após a Declaração em um artigo publicado no Semanário Voz Operária, criticou a aplicação dos ensinamentos do marxismo-leninismo, transformados em dogmas abstratos, em fórmulas gerais igualmente aplicáveis a todos os países, sem considerar suas particularidades, menosprezando o estudo da realidade; falou ainda sobre a radicalização das lutas que ao objetivar um resultado imediato, fechava os olhos para o processo político em desenvolvimento no país, isolando-se cada vez mais dos problemas imediatos que interessavam ao povo (SEGATTO, 1981, p. 78).

O processo autocrítico e a elaboração da nova política significaram para o PCB o começo de uma nova fase, mais ligada ao movimento democrático e nacionalista resultando na inserção do partido de forma mais ativa na sociedade brasileira. As mudanças propostas pelo partido defendiam o pluralismo e o policentrismo, a participação consciente dos trabalhadores na luta democrática do país e a conquista da hegemonia operária, sem ações golpistas e modelos insurrecionais, compreendendo o marxismo não mais como um conjunto de dogmas a serem seguidos ortodoxamente, mas sim um método de análise da conjuntura brasileira. O documento de 1958 também foi uma tentativa de resposta as exigências novas que se apresentavam à realidade do país: avanço do capitalismo, aceleração da urbanização, industrialização e modernização do aparelho estatal.

Em agosto de 1960, pouco mais de dois anos após a autocrítica, realizou-se o V Congresso do PCB, que confirmou as linhas gerais da Declaração de 1958. A partir desse momento a direção do partido passou a viver um período de turbulência, causada pelas diferentes interpretações de linha política, alimentando dessa forma divergências ideológicas entre as alas mais moderadas e as mais radicais no pré-64. O de liderança, tendo a frente Prestes e Giocondo Dias, defendia a importância de se juntar a burguesia nacional, enquanto Diógenes Arruda, João Amazonas e Maurício Grabois, 
grupo minoritário contrapunha-se a tais mudanças consideradas "direitistas" (MORAES; VIANA, 1982, p. 151).

Entre os anos de 1957 e 1960, o PCB passou por violentas críticas em seu interior, levantando entre seu grupo de dirigentes, posturas arrogantes e truculentas ainda comprometidas com o stalinismo, com o qual não pretendiam romper. A partir de 1961, esse grupo tido como reacionário, intensificou suas críticas à direção do PCB utilizando-se do Partido Comunista da China como referência e cujas posições, naquele momento, iam de encontro com as dos PCUS. Ainda no ano de 1961, o PCB realizou uma Conferência Nacional onde foi aprovado o estatuto que alterou o nome de Partido Comunista do Brasil para Partido Comunista Brasileiro, acirrando ainda mais as posições dentro do partido, o grupo dissidente considerou que tais alterações equivaleram ao abandono do marxismo e por esse motivo em fevereiro de 1962 consumou-se a defecção e a manutenção do nome Partido Comunista do Brasil, PC do B, um novo partido que objetivava a implantação do chamado "governo popular" através da "luta armada", distanciando cada vez mais o PCB do PC do B que adotaram concepções diversas sobre o marxismo e várias outras questões referentes à prática e a teoria (SEGATTO, 1981, p. 91-92).

O início da década de 1960 foi marcado pelo avanço das forças nacionais, democráticas e populares e por esse motivo o PCB e os comunistas, aos poucos foram recuperando sua influência no meio operário, no caso do PCB em grande parte devido ao reflexo da nova política formulada nos anos 50. O desenvolvimento das organizações e das lutas do operariado no início dos anos 60, com intensa participação dos comunistas ao lado dos trabalhistas, incluindo manifestações de apoio a João Goulart, foi determinante para a existência de um movimento operário - sindical ativo na vida política geral da nação e, sobretudo reivindicador de obras do Estado, como por exemplo, a exigência para que se realizassem as Reformas de Base. É necessário notificar que a influência e atuação do $\mathrm{PCB}$, nesse momento, não se reduziram somente ao movimento operário e aos trabalhadores do campo, mas estendeuse também a outros importantes setores da vida política nacional, por exemplo, movimento estudantil, intelectual e forças armadas. A proposta do PCB foi absorvida e defendida pelas forças nacional-populares, a ponto de ser identificada com a política do estado a ser realizada pelo governo. 
O PCB dedicou-se a luta pela legalidade e pela posse de João Goulart a presidência da república, pois sobre ele pesava a ameaça golpista de não Ihe ser passada a faixa presidencial após a renúncia de Jânio Quadros em agosto de 1961. A luta à causa da legalidade constitucional, aumentou e fortaleceu as mobilizações de trabalhadores no Brasil, ampliando significadamente o campo de atuação do PCB. Os comunistas desempenharam importante papel na organização da classe operária, através da criação de comissões e intersindicais, que na prática começariam a caminhar para o rompimento com a estrutura sindical pelega. Como exemplo podemos citar: Pacto de Unidade Intersindical, transformado depois no Pacto de Unidade e Ação (PUA) e o Comando Geral dos Trabalhadores (CGT) que coordenava e unificava a nível nacional o movimento sindical e suas lutas, o PCB também esteve presente nas lutas camponesas fazendo reivindicações imediatas pela reforma agrária culminando na fundação da (CONTAG), Confederação dos Trabalhadores na Agricultura (SEGATTO, 1981, p. 94).

$O$ aumento das mobilizações de trabalhadores e as Resoluções políticas no ano de 1962 permitiram ao partido a radicalização de sua postura, exigindo do então presidente da república João Goulart a implementação das Reformas de Base. No decorrer do processo, o PCB estabeleceu elos com a CGT, PTB, Frente Parlamentar Nacionalista (FPN) e Frente de Mobilização Popular (FMP), atingindo saldo positivo nas eleições de outubro de 1962, quando o partido abrigado em outras legendas, elegeu deputados federais e estaduais. Diante de tantos sucessos e conquistas adquiridos, o partido viveu um clima de euforia, acreditando estar no caminho de se tornar um "grande Partido Comunista, que seja poderoso do ponto de vista numérico, consciente e firme do ponto de vista político e ideológico, como propunha a Resolução política do V Congresso." (SILVA; SANTANA, 2007, p. 128).

Juntamente ao crescimento e avanço do PCB e demais forças nacional-populares, as forças conservadoras reacionárias e de direita passaram a sentir-se acuadas, vendo ameaçados seus interesses por isso começavam a conspirar e a organizar uma reação. Para piorar a situação o país no ano de 1962 passou por uma séria crise econômica que seria aproveitada pelas forças de direita que arquitetavam um golpe de Estado. No extremo oposto, as forças nacional-populares pressionavam o governo afim de 
que realizasse as reformas pretendidas, os trabalhadores foram incentivados a fazerem greves, tomarem terras e etc.

Jango foi se sentindo pressionado diante do conservadorismo do parlamento, que se tornou um entrave aos avanços das reformas defendidas pelo PCB. Já no início de 1964, com o governo enfraquecido, João Goulart lançou mais uma manobra política e apelou abertamente para o apoio popular. Em 13 de março de 1964, em frente a Central do Brasil, no Rio de Janeiro, o presidente realizou um comício de grandes proporções e, diante da multidão, anunciou medidas que integrariam um amplo projeto de reformas enviado dois dias depois ao Congresso Nacional. A reação não tardou, a CGT ameaçou fazer uma greve geral caso houvesse uma tentativa golpista, enquanto grupos conservadores queriam o impeachment do presidente, participando de atos como foi, por exemplo, a "Marcha da Família com Deus pela Liberdade." (SILVA; SANTANA, 2007, p. 130).

O ano de 1964 assistiu ao rápido enfraquecimento das bases políticas do governo, e no dia 31 de março desse mesmo ano, o golpe militar surpreendeu e impediu que os esforços dos comunistas e dos trabalhadores fossem recompensados.

2 GRAMSCI E O PCB: A LUTA MODERNIZANTE RUMO À REVOLUÇÃO PASSIVA

A década de 1950 representou um marco na história do PCB. O IV Congresso do 1954, a Declaração de Março em 1958 e principalmente, o XX Congresso do PCUS significaram o início de um processo de autocríticas, de mudanças que valorizavam as liberdades democráticas, mas que não aconteceram de forma tranqüila, já que muitos dirigentes do partido encontravam-se arredios a qualquer ruptura com o passado.

Em fevereiro de 1956, quando irromperam as primeiras notícias sobre o XX Congresso do Partido Comunista da União Soviética, o PCB passava por um período de otimismo. Os resultados obtidos com as formulações do programa de 1954, apesar de uma notória ausência de análise 
sobre o capitalismo e outros erros referentes a interpretação do processo histórico brasileiro, levaram certa motivação ao partido e seus dirigentes. A abertura dos arquivos secretos de Stálin, pelo secretário-geral do PCUS, Nikita Kruchev, levou ao conhecimento do mundo as atrocidades cometidas durante $\mathrm{O}$ governo stalinista, revelações que provocaram perplexidade entre os comunistas, comprometidos há anos com a assimilação do marxismoleninismo.

Os novos tempos marcaram o fechamento do PCB em um período de discussão, não era fácil acreditar na veracidade dos crimes denunciados. Notícias sobre a evolução dos acontecimentos em outros PC's chegavam insistentemente, dando conta sobre a denúncia do culto à personalidade e a necessidade de se repensar a realidade com a social-democracia e um novo caminho para o socialismo, já que o arcabouço teórico era colocado em dúvida. As primeiras notícias veiculadas na imprensa comunista, Voz Operária e Imprensa Popular, davam um tom oficioso às questões relativas ao $\mathrm{XX}$ Congresso, diminuindo a verdadeira dimensão dos debates que aconteciam em outros partidos comunistas. As matérias traziam resoluções do Partido Comunista Italiano, um exemplo que mais avançou nos debates. Foi publicado também, no jornal Estado de São Paulo, um artigo de Eugene Dennis, secretário-geral do PC Americano, que afirmava a legitimidade dos documentos apresentados por Kruchev, mas o artigo foi considerado armação da imprensa burguesa (SANTOS, 1988, p. 100).

Os documentos produzidos pelo partido comunista italiano, não só confirmaram elementos da problemática na União Soviética, como também retiraram o PCB da passividade em que se encontrava, apresentando novas possibilidades de discussão, com a participação das grandes massas de trabalhadores. Muitos partidos comunistas, para um processo mais aberto e completo de desestalinização, saíram a público, delineando uma posição autocrítica $e$ até mesmo substituindo $o$ quadro de dirigentes mais comprometidos com o passado (SANTOS, 1988, p. 102).

O mundo comunista conhecia a crise e o difícil processo de substituição do stalinismo e diante disso a perplexidade dos comunistas brasileiros que prolongavam os meses de silêncio em que permanecia a direção partidária. Pode-se dizer que o silêncio foi sendo quebrado aos poucos, 
quando os dirigentes do PCB entraram em contato com o informe de Palmiro Togliatti ${ }^{7}$, apresentado no VIII Congresso do PCI. O documento refletia sobre a orientação a ser definida para o partido, além de abordar questões de valor mais geral, a nova bagagem teórica do partido italiano destacava conceitos gramscianos $^{8}$. Togliatti procurava vias originais para o socialismo. Reconheceu questões equivocadamente defendidas pelo PCUS, como foi o caso do centro único, aceito pelo PC's durante muitos anos e a necessidade de reformas nas instituições russas o que trouxe para discussão temas polêmicos, muitas vezes evitados.

A proposta de uma nova política pensada por Togliatti e açambarcada pela teoria de Gramsci daria um novo enfoque a luta das massas, defenderia a implantação da democracia interna com o objetivo de construir um partido conscientizador capaz de transpor a fase meramente agitativa. Não há como precisar exatamente quais foram as influências que os informes do partido comunista italiano provocaram no PCB, mas é certo que as preocupações de Togliatti foram evidenciadas em debates no interior do partido. Os novos caminhos traçados para o socialismo aumentaram 0 interesse dos dirigentes, estimulando e pressionando a abertura dos debates.

A contra gosto da dirigência partidária, em 6 de outubro de 1956, o Voz Operária trazia um artigo de João Batista de Lima e Silva com o seguinte título: "Não se poderia adiar uma discussão que já está em todas as cabeças", irrompendo dessa forma os debates. Os primeiros artigos e cartas reclamavam da demora e atraso da imprensa pecebista em se pronunciar a respeito das revelações do XX Congresso do PCUS. A abertura dos debates incitou a publicação de diversos artigos, sendo a maioria da autoria de intelectuais comunistas. Dentre as publicações havia diferenciações de idéias, enquanto alguns intelectuais procuravam estreitar e simplificar as discussões, outros pediam para que os debates fossem amplos e aprofundados (SANTOS, 1988, p. 115).

As edições seguintes do Voz Operária publicaram o "Projeto de Resolução do Comitê Central do PCB sobre os ensinamentos do XX Congresso do Partido Comunista da União Soviética, o culto à personalidade $\mathrm{e}$ suas conseqüências, a atividade e as tarefas do Partido Comunista do Brasil", (SANTOS, 2003, p. 236) uma maneira que a direção partidária encontrou para 
dirigir e orientar os debates. Sem um exame crítico da realidade, o projeto de resolução tratou superficialmente dos problemas essenciais referentes à discussão, apenas reproduziu a análise da situação internacional feita nos documentos soviéticos, sem maiores reflexões. As resoluções também abordaram repetitivamente questões vigentes na plataforma do Pleno de 1955 como: política externa de paz, defesa das liberdades democráticas, melhoria das condições de vida dos trabalhadores, etc.

Quanto às disposições relativas ao XX Congresso e seus ensinamentos, o projeto de resolução não alcançou grandes avanços, permanecendo na justificativa histórica dos erros de Stálin, associou-se o "culto" no interior do PCB às manifestações empíricas do dogmatismo subjetivista, mas sem nenhuma análise mais profunda do pensamento político. Ainda durante o ano de 1956, a imprensa partidária continuou trazendo artigos, geralmente críticos e questionadores das concepções práticas do PCB, um número bastante grande desses artigos pedia a redefinição de pontos do programa de 1954, apoiados na tese da nova realidade do país. Dessa maneira, o início dos debates acabou dividindo, ou melhor, reforçando a divisão de opiniões, entre os críticos do desempenho do partido, propondo a adesão de elementos novos à política pecebista e aqueles ainda em clima formalmente autocrítico, preconizando certo defensismo, a espera de respostas do coletivo partidário.

A crise político-ideológica pela qual passava o PCB aproximou-o de alguns elementos das formulações teórico-políticas de Antônio Gramsci, reelaboradas pelo já mencionado secretário-geral do partido comunista italiano (PCl), Palmiro Togliatti. É importante destacar que as idéias de Gramsci, embora reelaboradas, foram conhecidas pelos brasileiros comunistas e influenciaram o processo de renovação vivido pelo PCB nos anos 1958-60 (SEGATTO, 1998, p. 182).

A Declaração de Março de 1958 traz claras evidências das influências sofridas pelas elaborações de Gramsci, alguns conceitos presentes na obra desse autor foram incorporados aos documentos do PCB. Embora utilizados sem muitas propriedades, passaram a fazer parte do vocabulário pecebista questões como a democracia, fundamental na luta pelo socialismo, a preocupação na conscientização das massas, a coesão do partido político, a 
estratégia das frentes democráticas, a busca pelo caminho pacífico na revolução brasileira, fazendo uma clara aproximação com conceitos gramscianos, como: hegemonia, partido político, inversão da infra e superestrutura, revolução passiva. Já indicavam as proposições da Declaração de Março:

\begin{abstract}
As tarefas impostas pela necessidade do desenvolvimento independente e progressista do país não podem ser resolvidos por nenhuma força social isoladamente [...] A experiência da vida política brasileira tem demonstrado que as vitórias antiimperialistas e democráticas só puderam ser obtidas pela atuação em frente única daquelas forças [...] Sendo inevitavelmente heterogênea, a frente única nacionalista e democrática encerra contradições. [...] $\mathrm{O}$ proletariado tem interesse no desenvolvimento antiimperialista e democrático conseqüente [...] O proletariado deve salvaguardar, por isto, a sua independência ideológica, política e organizativa dentro da frente única [...] A conquista da hegemonia do proletariado é, porém, um processo de luta árduo e paulatino, que avançará à medida em que a classe operária forjar a sua unidade, estabelecer laços de aliança com os camponeses e defender de modo acertado os interesses comuns de todas as forças que participam da frente única (DECLARAÇÃO SOBRE A POLÍTICA DO PARTIDO COMUNISTA BRASILEIRO, 1958 apud SEGATTO, 1981, p. 80-81).
\end{abstract}

Gramsci se tornou um mito no interior da esquerda italiana, era apresentado como um antecipador das renovações que se faziam necessárias das teorias e práticas marxistas-leninistas, bem como de uma nova caracterização para a revolução socialista. Libertário e reformista, Gramsci desapareceu com as separações entre o econômico, o social e o político, em sua teoria há uma "politização do social" e uma "socialização da política". Estudou muitos temas, tais como hegemonia política, poder na sociedade civil, o papel do Estado, a função dos intelectuais na sociedade, a cultura, o folclore etc. Tratou também especificadamente do partido comunista, com o objetivo de demonstrar como era complexa, mas indispensável a formulação da teoria da organização e a prática organizativa do partido (GRAMSCI, 2006, p. 47).

O PCB e outros PC's viviam um novo momento, advindo com o colapso das imposições stalinistas. Era preciso repensar as teorias e práticas, que naquela conjuntura aclamavam por liberdades democráticas. As revoluções experimentaram o gosto da derrota, o XX Congresso do PCUS, 
esfacelou o ideário marxista-leninista e por que não dizer stalinista? Gramsci se apresentou ao $\mathrm{PCl}$, ao mundo e ao $\mathrm{PCB}$, com um marxismo renovado, libertário, capaz de promover transformações na ação política e particularmente na ação revolucionária. Ao analisar-se as proposições da Declaração de Março citada anteriormente, verifica-se o processo de renovação pelo qual o partido passava, e mais ainda, a influente marca gramsciana.

Gramsci fala sobre hegemonia política, um conceito que se refere ao funcionamento e conquista da direção ideológica da sociedade por uma classe, ou seja, esse conceito transportado para a realidade brasileira e dominado pelo PCB, significaria a passagem do comando revolucionário ao proletariado, que assumiria a posição de classe hegemônica ideologicamente, responsável pelo desenvolvimento orgânico da concepção de mundo da classe subalterna. Segundo o italiano:

\begin{abstract}
A supremacia de um grupo social se manifesta de duas maneiras: como 'domínio' e como 'direção intelectual e moral'. Um grupo social é dominante dos grupos adversários que tende a 'liquidar' ou a submeter também mediante a força armada, e é dirigente dos grupos afins ou aliados." (GRAMSCI, 1984, p.2010 apud NOGUEIRA, 1998, p. 87-88).
\end{abstract}

A hegemonia se estabelece a partir das relações entre Estado/Sociedade, é no processo de socialização do Estado que o poder estatal não se expressa apenas por meio de seus aparelhos repressivos e coercitivos, mas mediante uma nova esfera social, a sociedade civil, que englobará as classes subalternas e seus interesses. O PCB tomou para si a função de gerar na classe operária, a consciência crítica, o início para a consciência de classe, influenciando e promovendo o desenvolvimento independente e progressista do país, dentro da frente única, resguardando a independência político-ideológica. A nova política pecebista traçava projetos claros para a hegemonia proletária: "A tarefa principal e permanente do movimento comunista consiste em unir e organizar a classe operária, elevar sua consciência e dirigir a sua luta, para que ela possa desempenhar sua função dirigente na sociedade brasileira." (SEGATTO, 1981, p. 93). 
A passagem do Estado de massas para o Estado consciente, com a sociedade civil fortalecida, prenunciava alterações nas formas de ações políticas e revolucionárias. O confronto direto deu lugar a "guerra de posições", mais apropriada para o período pós-guerra. Para Gramsci não se tratava de uma escolha entre uma maneira e outra, mas uma imposição da realidade histórica mundial, nascida das transformações políticas e sociais. O teórico valeu-se de uma analogia militar: "não se pode escolher a forma de guerra que se quer, a menos que se tenha uma superioridade esmagadora sobre 0 inimigo." (GRAMSCI, 1984, p. 1615 apud NOGUEIRA, 1998, p. 86).

O mesmo faz ainda uma referência a superestrutura da sociedade civil, que funcionaria como trincheiras na guerra moderna, pois sua complexidade evitaria quebras catastróficas do elemento econômico. Segundo o PCB:

O povo brasileiro pode resolver pacificamente os seus problemas básicos com a acumulação, gradual mas incessante, de reformas profundas e consequentes na estrutura econômica e nas instituições políticas, chegando-se até a realização completa das transformações radicais colocadas na ordem do dia pelo próprio desenvolvimento econômico e social da nação (NOGUEIRA, 1980, p. 22 apud VIANNA, 1998, p. 195-196).

O momento não era mais o das "minorias revolucionárias", mas do proletariado hegemônico, não era mais das "barricadas e das lutas de rua", mas das batalhas eleitorais. O sufrágio universal transformava-se numa arma para os operários, permitindo-os um novo método de luta e um contato mais amplo com a sociedade civil. A revolução passiva seria a incorporação, do elemento ativo, dotado de consciência política ao processo de transformismo em curso, que se fazia indicar pelo nacional-desenvolvimentismo, programa que devia conduzir a um capitalismo estatal a base de uma coalizão nacionalpopular.

Para o PCB, a revolução passiva seria a base de implantação do regime nacional-democrático, pois permitiria o ascenso do movimento operário e o desenvolvimento da frente única nacionalista e democrática em nosso país: 
O caminho pacífico significa a atuação de todas as correntes antiimperialistas dentro da legalidade democrática e constitucional, com a utilização de formas legais de luta e de organização de massas. É necessário, pois, defender esta legalidade e estendê-la, em benefício das massas (NOGUEIRA, 1980, p. 22 apud SEGATTO, 1998, p. 182).

A Declaração de Março de 1958 seria pela primeira vez na história da esquerda brasileira a identificação com o conceito de Revolução Passiva, uma proposta de ruptura não baseada no "momento explosivo de tipo francês". A Revolução Passiva deixava de ser cenário exclusivo das elites, passando a incorporar o projeto de ação da antítese, objetivando introduzir o elemento ativo no processo de transformismo em curso. "A esquerda descobria o tema do transformismo como uma nova alternativa para a mudança social, mas esta descoberta, porém, se fazia em um terreno estranho ao seu - o do Estado, da burguesia nacional e das elites políticas de tradição territorialista." (VIANNA, 1998, p. 196).

Outro conceito importante elaborado por Gramsci e apropriado pelos comunistas brasileiros foi o de partido político, uma forma de manter a coesão entre os dirigentes partidários, criando uma possibilidade de identidade ideológica entre seus militantes. O partido comunista seria o instrumento e a forma histórica para o processo de libertação, sendo que através dele 0 operário passaria de executor à iniciador, de massa à poder hegemônico, de trabalhador braçal converteria-se em cérebro e ideologia, objetivando o pleno desenvolvimento do estado operário, organizado e com as condições materiais necessárias (GRAMSCI, 2006, p. 56-57).

O PCB representaria a unidade entre os operários, a representação e identificação do proletariado com a ideologia e luta em curso. O partido centralizaria no plano nacional, o elemento dotado de força altamente coesiva e disciplinadora, capaz de concentrar e organizar objetivos comuns, mesmo em um estado disperso e errante.

Esses foram os conceitos adaptados pelo PCB à realidade histórica brasileira. Gramsci por ter sido um pensador marxista, mas dotado de uma visão crítica e histórica dos processos sociais, capacitou a dirigência brasileira 
para a transformação política em andamento, possibilitando o tratamento do marxismo, não como doutrina abstrata como fazia o PCUS, mas como método de análise concreta da realidade em suas diferentes determinações.

A década de 50 significou para 0 PCB 0 momento das transformações e organizações ulteriores. O partido, a partir de novas iniciativas, processou reformulações em seu projeto político, deixando que a principal mudança ficasse a cargo do proletariado, que seria capacitado para a liderança ideológica do movimento revolucionário. Esse processo talvez possa ser a síntese de todo o projeto gramsciano. O momento da passagem de "classe em si" para "classe para si", traduz o pensamento denominado por Gramsci como catarse, que significaria essa transição da esfera egoísticopassional, ou seja, os interesses meramente corporativos e particulares, ao ético-político, ou nível da consciência universal.

Assim como já foi citado anteriormente, essa aproximação do PCB com os documentos do Partido Comunista Italiano e as práticas de Gramsci, nunca se fez de forma tranqüila, ao contrário, sempre encontrou resistências, daí caracterizando uma reforma restrita, cheia de ambigüidades, que pouco valia na prática. O projeto político de Gramsci foi com certa freqüência misturado e até mesmo subordinado aos velhos princípios do marxismoleninismo. Para exemplificar, Carlos Nélson Coutinho afirma:

Em suas formulações estratégicas, continha a própria imagem de um Brasil 'atrasado', semifeudal e semicolonial, carente de uma revolução 'democrático-burguesa' ou de 'libertação nacional' como condição necessária para encontrar o caminho do progresso social." (1988, p. 60 apud SEGATTO, 1998, p. 184).

A introdução das idéias de Antônio Gramsci na vida política brasileira foi dificultada por diversos fatores, entre eles, ressalta-se a problemática realidade histórica pensada por seus intelectuais, uma realidade adversa, imbuída de uma cultura política atrasada e antidemocrática, uma esquerda ainda predominantemente comandada por pelo dogmatismo e atitudes sectárias. Com todos esses os problemas as idéias de Gramsci foram 
vistas com extrema desconfiança pela maioria dos agrupamentos de esquerda e como sinal de "reformismo" e "pacifismo".

De qualquer forma, contando com todas as limitações, o projeto do $\mathrm{PCl}$ e as propostas gramscianas contribuíram e fizeram parte da reforma pecebista, atribuindo concepções e práticas ainda que conservadoras à renovação do PCB, com uma certa receptividade teórica.

\section{DA TEORIA À PRÁTICA: A ATUAÇÃO DOS COMUNISTAS NOS MOVIMENTOS NACIONAL-POPULARES NA DÉCADA DE 60}

Os anos que se seguiram ao processo de autocríticas, desencadeados após o XX Congresso do PCUS, marcaram um importante desempenho do PCB na vida política nacional. A democracia brasileira entre 1955 e 1964 permitiu aos comunistas maiores espaços para a participação, fazendo com que aos poucos, estes recuperassem sua influência no seio da classe operária. Após um período de dogmatismos e sectarismo, O PCB intensificou suas ações, sendo o eixo central da política comunista no movimento operário, camponês e sindical.

A mudança da linha política pela qual o PCB passou nos anos 50 aproximou-o de uma política de unidade e aliança com setores nacionalistas, principalmente trabalhistas e sindicalistas, facilitando a mobilização da classe operária e suas reivindicações:

A união dos trabalhadores de orientação comunista, trabalhista, socialista, católica e dos trabalhadores sem filiação partidária, é a arma principal de que dispõe a classe operária para lutar por seus interesses [...] A unidade sindical só pode ser alcançada através da unidade de ação dos trabalhadores em torno às reivindicações comuns e mais sentidas, por mais elementares que sejam. A fim de obter-se essa unidade de ação, é necessário utilizar-se as conquistas da legislação social vigente e procurar concretizá-las e aperfeiçoá-las, influindo sobre o Parlamento com a pressão de massas para conseguir a aprovação de novas leis (TELLES, [195--] apud SEGATTO, 1981, p. 93-94). 
Para que se possa ilustrar e exemplificar a política de unidade levada pelo PCB, vale lembrar o apoio dado pelo partido aos governos de Juscelino Kubitschek (1956-60) e depois a Jango, vice-presidente de Jânio Quadros (1961), no momento da renúncia deste.

Quando, em 25 de agosto de 1961, Jânio Quadros surpreendeu a nação ao anunciar sua renúncia, provocou uma crise em termos de sucessão. Muitos militares e setores conservadores tentaram impedir a posse de João Goulart. Setores constitucionalistas e o movimento sindical progressista paralisou trabalhadores em diversas áreas a favor da legalidade constitucional. À frente do movimento estavam comunistas e trabalhistas em apoio integral a Jango.

O desenvolvimento e avanço das forças nacional-populares, ou mesmo aliança entre comunistas-trabalhistas, aumentaram a organização dos trabalhadores e colocaram na ordem do dia a importância de se realizar um conjunto de obras e reformas econômicas, políticas e sociais, reformas democráticas que incluíssem entre outras, a reforma agrária e melhorias nas condições de vida dos trabalhadores. A aproximação do PCB com trabalhadores rurais surtiria efeitos positivos que serão verificados adiante.

O período entre os anos 1955 e 1964, de forma geral, gozou dos ares de liberdade, e com ele o PCB, que se aliou aos trabalhistas, através das chamadas organizações intersindicais. Para se ter uma idéia sobre o volume dessas entidades, podemos citar entre outras, a Comissão Permanente das Organizações Sindicais (CPOS), que agrupava sindicatos do Distrito Federal; o Fórum Sindical de Debates (FSD); o Pacto de Unidade e Ação, que congregava ferroviários, portuários e estivadores de todo o Brasil (PUA) e o Pacto de Ação Conjunta (PAC). O ápice de todo esse processo se deu com a criação do Comando Geral dos Trabalhadores (CGT), que aglomeraria, no plano nacional todas as questões propostas pelas outras entidades.

Assim ficou definida a participação do proletariado na aliança comunista-trabalhista ou simplesmente frente única, termo criado e utilizado pelo PCB: 
A classe operária, através de sua vanguarda comunista, não condiciona sua participação na frente única a uma prévia direção do movimento. A hegemonia do proletariado deve ser conquistada como resultado de um processo de luta árduo e paulatino, durante o qual a classe operária forja sua unidade, estabelece uma sólida aliança com os camponeses - seu aliado fundamental - e defende acertadamente os interesses comuns de todos as forças que participam da frente única (PCB: VINTE ANOS DE POLÍTICA, 1980 apud SEGATTO, 1981, p. 88).

A política de unidade, que passou a ser praticada pelo PCB no movimento operário e sindical, teve como conseqüência um significativo avanço das lutas e das organizações dos trabalhadores. As quais através da criação de comissões, conquistaram algumas direções importantes, como foi o caso da Confederação Nacional dos Trabalhadores na Indústria (CNTI). A "grande ofensiva" coroou o sucesso da aliança sobre a confederação mais simbólica e importante naquele momento. Em 1961, comunistas e trabalhistas derrotaram os membros conservadores da CNTI, que dirigiam a entidade desde a década de 40. Ocuparam a direção, com reivindicações imediatas para a transformação social. A direção da CNTI representou mais um passo importante. Garantiu à aliança o comando dos setores reformistas sobre muitos sindicatos e federações ligadas ao ramo industrial espalhadas por todo o Brasil (SANTANA, 2007, p. 267).

A criação das intersindicais pelo PCB e demais forças nacionalpopulares, ressaltando-se principalmente as trabalhistas, objetivava romper com a estrutura sindical vertical, fazendo frente ao controle exercido pelos setores "pelegos". Ao mesmo tempo, criou-se um outro tipo de organização, preocupado com a vivacidade da classe, procurando afastar das decisões sindicais os setores mais conservadores. $O$ fato foi que a aliança ao mesmo tempo buscou "crescer para baixo", motivando agitações no interior das fábricas, mas também se esforçou no sentido de "crescer para cima", ou seja, ocupou postos-chave no interior da estrutura sindical e conseqüentemente, procurou incorporar os trabalhadores nas decisões (SANTANA, 2007, p. 263).

Em 1964, para dimensionar o avanço da aliança comunistatrabalhista no interior do sindicalismo nacional, pode-se contabilizar quatro das seis confederações oficiais então existentes, que passaram à direção da 
aliança. São elas: a Confederação Nacional dos Trabalhadores na Indústria (CNTI), a Confederação Nacional dos Trabalhadores em Estabelecimentos de Crédito (Contec), a Confederação Nacional dos Trabalhadores Marítimos, Fluviais e Aeronáuticos (CNTMFA) e a recém criada Confederação Nacional dos Trabalhadores na Agricultura (Contag). Quanto a Contag, essa foi símbolo da união entre o PCB e os trabalhadores rurais e do engajamento do trabalhador agrícola na luta pela reforma agrária. O Ministério do Trabalho reconheceu os sindicatos rurais e promulgou o Estatuto do Trabalhador Rural.

As investidas da aliança tomaram impetuosamente setores representativos e estratégicos naquele momento. O sucesso entre comunistas e trabalhistas deveu-se, em grande parte, à estratégia utilizada, ou seja, a conquista tanto das bases sindicais quanto de seus instrumentos de cúpula. Evitou-se que o trabalhador estivesse sozinho, em movimento autônomo, fazendo prevalecer a política de unidade. Tal situação não foi suficiente para que o governo perdesse totalmente o controle sobre os sindicatos e a estrutura sindical oficial se manteve intacta. De acordo com Marco Aurélio Santana:

\begin{abstract}
A estrutura se manteve, entre outros motivos, porque as lideranças sindicais, se queriam autonomia de ação e se opunham às intervenções do Estado, defendiam a manutenção dos pontos-chave do corporativismo, que facilitavam seu controle sobre a 'máquina': unidade sindical e arrecadação compulsória da contribuição tanto de associados como de não-associados (2007, p. 264).
\end{abstract}

Mesmo que na prática houve a manutenção de alguns pontos-chave dos projetos estatais, não se pode minimizar, ou até mesmo desprezar a política posta em prática pela aliança, que mostrou todo o seu vigor na organização e estruturação de muitos órgãos intersindicais. Os quais participavam ativamente dos debates sobre os caminhos e destinos da sociedade brasileira. Outros processos envolveram a participação da aliança, como a conformação da Frente de Mobilização Popular (FMP), que unificou grupos orientados pelas posições nacionalistas de esquerda. Dentre esses grupos estavam: A União Nacional dos Estudantes (UNE) e deputados da Frente Parlamentar Nacionalista (FPN). 
A aliança desempenhou fator decisivo à frente das grandes jornadas cívicas. Conquistou importantes vitórias políticas ao lado dos trabalhadores contra as forças reacionárias, de direita e pró-imperialistas. Assim um órgão em São Paulo avaliou o desempenho da aliança, em 1957 (SANTANA, 2007, p. 264-265).

O momento também foi marcado não apenas pelo movimento sindical, mas pela experiência democrática colocada em prática através de greves e paralisações em diversas cidades. Como foi o caso da dos têxteis em Recife, a dos 400 mil em São Paulo (1957), a dos trabalhadores das barcas Rio-Niterói (1959) e a Greve da Paridade (1960), quando trabalhadores civis paralisaram os transportes marítimos, ferroviários e portuários em todo o país. No período em que João Goulart esteve a frente da Presidência da República, os sindicatos decretavam greves em apoio e solidariedade a Jango, atingindo principalmente as atividades industriais e de transportes no Rio de Janeiro.

Em setembro de 1962, uma greve geral marcou a trajetória de comunistas e trabalhistas. A aliança promoveu um plebiscito que derrotou maciçamente o regime parlamentarista. Ainda na mesma ocasião, reivindicouse a revogação da Lei de Segurança Nacional, direito de voto a todos os cidadãos, incluindo analfabetos e soldados, concessão do direito de greve, aumento salarial de $100 \%$ e outros. Durante os períodos de crises políticas, a aliança comunistas-trabalhistas, e obviamente o PCB, se posicionaram ao lado da democracia e da legalidade. Observa-se as seguintes proposições do PCB:

Os comunistas atuam, por isso, nos marcos da estrutura sindical e observam a Consoidação das Leis do Trabalho, procurando dentro da lei organizar e unir os trabalhadores na luta por suas reivindicações econômicas, sociais e políticas[...] A unidade só pode ser conseguida em bases sólidas e duradouras se o movimento sindical contar com a participação ativadas massas trabalhadoras, se não for um movimento apenas de cúpula (TELLES, [195--] apud SEGATTO, 1981, p. 94).

A atuação do PCB não se reduziu apenas ao movimento operário e camponês, mas se alargou para outros importantes setores da vida política nacional: movimento estudantil, movimento intelectual, Forças Armadas etc. As forças nacional-polpulares avançavam em luta e com ela a proposta política do 
PCB ia sendo defendida e absorvida como bandeira de luta por diversos setores da sociedade civil.

A participação foi intensificada quando houve a posse de João Goulart após renuncia de Jânio Quadros. Defendendo as reformas de base, acentuando seu projeto reformista, o então presidente, aliou-se ao movimento de trabalhadores, com pretensão de alcançar seus objetivos. Por outro lado, os trabalhadores se aproveitaram de tal situação e dos espaços concedidos por Jango, para o avanço do movimento e de suas conquistas. Após esse momento, houve uma aproximação das propostas do PCB, com as propostas governamentais, como sugere Segatto: "A luta popular passou a convergir, em diferentes e múltiplos momentos, com a atividade política governamental". Ainda exemplifica: "Pontos altos dessa convergência foram o comício do dia 13 de março e a mensagem presidencial sobre as reformas de base enviadas ao Congresso Nacional” (1981, p. 92).

A aproximação da aliança comunistas-trabalhistas com o governo permitiu um auxílio mútuo fundamental para as conquistas democráticas, retirando, em alguns momentos, o poder das mãos de setores conservadores. A aliança transformou o poder sindicalista em força política e apoio político capaz de realizar importantes mobilizações em favor dos trabalhadores.

Apesar de todo o sucesso que a aliança vinha conquistando, comunistas e trabalhistas, por vezes chegavam a divergir em suas decisões. Por mais que houvesse uma unidade de interesses, seus projetos políticos não eram os mesmos. Como já foi mencionado, O PCB há muito falava sobre a política de unidade, considerada, principalmente a partir de 1954, uma alternativa para seu desenvolvimento. Foi essa ideologia que aproximou comunistas a outros setores, modificando a maneira de atuação do movimento sindical nacional dentro e fora da estrutura corporativa.

É importante ressaltar que o destaque do movimento ficou para os comunistas, que estavam defendendo seu projeto político junto aos trabalhadores. O PCB aproveitou-se dos espaços conquistados para o empreendimento de seus ideais. Por trás da aliança, havia uma competição, que de forma estratégica procurava o avanço de posições sobre os demais aliados.

Da seguinte forma um militante comunista definiu a aliança: 
Nós participávamos da unidade, da forma que o partido sempre fazia. Visando mais à frente derrotar o aliado. No momento mesmo em que começava a aliança, para o partido o aliado já estava com os dias contados (SANTANA, 1992, p. 167 apud SANTANA, 2007, p. 267).

Assim, quando às vezes as posições divergiam, os partidos se atacavam criticando o que, na visão de cada um deles, não corresponderia aos interesses dos trabalhadores. Benedito Cerqueira, presidente do Sindicato dos Metalúrgicos do Rio de Janeiro e militante trabalhista, se posicionou da seguinte forma quanto ao PCB:

o PCB também não é o partido que mais convém aos trabalhadores. Além de estar na ilegalidade, cometeu, quando tinha vida normal, tremendos erros. Alijou destemidos combatentes de seus quadros.[...] O PCB nunca esteve efetivamente nas mãos dos operários (CERQUEIRA, 1961 apud SANTANA, 2007, p. 268).

Em resposta às proposições de Cerqueira, o pecebista Jover Telles alegou ser o PCB sim o partido da classe operária. Que a ilegalidade partidária seria prova de que os comunistas defendiam a causa trabalhista e por isso teriam sido impedidos de atuar. Dessa maneira, as propostas iniciais da aliança foram se esfacelando, os interesses partidários passaram a se sobressair sobre os interesses da classe trabalhadora. O próprio presidente João Goulart tentou sem sucesso arrefecer a força aliancista.

A disputa que se acirrou entre comunistas e trabalhistas, junto ao pronunciamento de Jango, em favor da continuidade da aliança, fez com que as elites temessem o comunismo. Rapidamente, setores da direita se articularam e deram o golpe no regime constitucional, destituindo o presidente e transformando escolhas em normas.

O PCB incorreu em uma série de erros que o levaram a cegueira política, o inimigo do Brasil ainda era externo, assim os principais esforços se voltavam para o combate ao imperialismo norte americano. A renovação pela qual passou o partido não foi suficiente para que se fizesse uma análise correta 
da conjuntura brasileira. Tanto trabalhistas quanto comunistas não perceberam o inimigo interno que febrilmente preparava o golpe de Estado.

\begin{abstract}
No instante em que eclodiu o movimento militar pela derrubada do governo, o povo encontrou-se desarmado politicamente para enfrentar os golpistas... As forças populares viram-se diante de um fato que não estava previsto em seus cálculos, ficando hemiplégicos ao anunciar-se o movimento militar nas Alterosas[...] Toda a tática das correntes progressistas e do próprio governo Goulart encontravase apoiada numa base falsa: não havia uma justa análise da correlação de forças e do desenrolar do processo (TAVARES, 1966, p. 32 apud SEGATTO, 1981, p. 99).
\end{abstract}

No início de 1964, verificou-se um declínio do apoio político dado pelos comunistas e setores trabalhistas ao governo, com relativa perda de importância entre os setores populares e rápido enfraquecimento das bases políticas do mesmo.

A luta pela democracia e pela legalidade constitucional, fez com que o PCB, não se articulasse perante um golpe de Estado. A constante busca pela implementação da Revolução Passiva e outros conceitos gramscianos impediram que o partido se posicionasse de forma mais agressiva e até mesmo golpista. O PCB empenhou-se muito mais numa possível revolução intelectual no meio operário, uma maneira de conscientização política da classe, que através do sufrágio universal levaria ao poder representantes do socialismo. Pretendia esquecer os anos de revolta, que marcaram os primeiros anos de sua existência de maneira negativa e sem sucessos. Assim o partido se expressou sobre a velha maneira de agir:

A tática, para nós, se reduzia assim à pura agitação e ao desencadeamento de lutas que procurávamos radicalizar artificialmente, visando ganhar as massas para o programa revolucionário, enquanto esperávamos a chegada do momento propício em que, por meio da insurreição, substituiríamos as classes no Poder. Só víamos, deste modo, a meta a atingir, que colocávamos arbitrariamente como objetivo imediato, e não o movimento real no qual devíamos nos integrar, procurando conduzi-lo no sentido da meta revolucionária [...] Com esta compreensão simplista e mecânica da revolução, cerrávamos os olhos ao processo político em desenvolvimento no país, e, em geral, dele não participávamos como força política atuante (PCB: vinte anos de política, 1980 apud SEGATTO, 1981, p. 84-85). 
E depois um alerta para a nova tática:

\begin{abstract}
A crítica superficial de nossos erros políticos pode conduzir agora ao erro oposto, à preocupação exclusiva com o movimento que se processa gradualmente, abandonando a meta revolucionária da classe operária. Ora, uma tática que se baseia apenas nas conquistas imediatas e não objetiva atingir as transformações radicais nada tem de uma tática revolucionária, mas, pelo contrário, é uma tática reformista, que nos colocaria a reboque da burguesia (PCB: vinte anos de política, 1980 apud SEGATTO, 1981, p. 85).
\end{abstract}

O golpe de $1^{\circ}$ de Abril implantou no país uma ditadura baseada na força militar, na repressão policial e no autoritarismo coercitivo. Mais uma vez os trabalhadores iriam sofrer os abusos das elites brasileiras. $O$ árduo trabalho realizado pelas frentes populares e uma geração de militantes político-sindicais havia sido jogado fora. A partir desse momento, dirigentes e militantes do PCB foram perseguidos, torturados, presos e em muitos casos assassinados, acusados de inimigos da pátria e da democracia. A esquerda novamente foi para a prisão. Conheceu a interrupção de seus projetos em pleno ápice de suas atividades. O PCB iria passar por um novo momento de silêncio e por um processo de autocríticas devido a amarga derrota sofrida.

\title{
5 CONSIDERAÇÕES FINAIS
}

A nova política esboçada pelo PCB nos anos 50, fruto principalmente dos desdobramentos do XX Congresso do PCUS baseou-se na defesa do pluralismo e do policentrismo, na conscientização e unidade das grandes massas no processo político. A nova orientação se definiu já na Declaração de Março de 1958, quando se iniciou o processo de autocríticas, caracterizando uma política diferente daquela seguida anteriormente.

A tentativa de compreender o marxismo não como um conjunto de dogmas, mas como um método de análise da realidade histórica, levou o PCB a um longo período de renovação, que na prática aconteceu misturada a resquícios de dogmatismos e sectarismos. As discussões nunca foram 
aprofundadas o suficiente, ao contrário, foram muitas vezes escamoteadas, optando-se pela conciliação interna, pela adaptação das divergências ou por soluções entre os dirigentes.

Apesar de todos os problemas que continuavam a existir, o PCB se inseriu de forma ativa na vida política brasileira. No início da década de 60, o partido conquistou a vanguarda no avanço das forças nacional-populares, incorporando a prática democrática e defendendo a inversão do processo histórico autoritário e reacionário. Contudo, permaneceu alheio as questões internas. Não foi capaz de prever uma reação das forças conservadoras, reacionárias e de direita que, naquele momento, começavam a sentir-se ameaçadas e atemorizadas com o crescimento do movimento democrático.

Antes mesmo que o projeto pecebista tomasse corpo, ele foi interrompido pelas forças de reação, que no dia $1^{\circ}$ de abril de 1964 deram o golpe e implantaram no Brasil um regime ditatorial. Desde então, o partido passou a ter uma vida dura e difícil, sendo vítima de discriminações e violências sem limites sem, no entanto abandonar seus projetos políticos.

O partido da classe operária pensou que através das vias democráticas e legais, seria possível levar ao poder os trabalhadores, partindo do pressuposto de que a classe estava se conscientizando politicamente, o que de fato não estava acontecendo. Grande parte dos operários e trabalhadores de outras áreas permaneceram a margem do processo. Dessa maneira houve uma discordância entre a esquerda e a direita que logo partiu para a ação golpista.

O PCB, mesmo com uma longa e difícil história de lutas pela organização da classe operária e dos trabalhadores em geral, soube acumular experiências e enraizar-se na sociedade nacional. Soube sair de suas crises apresentando propostas que atraíssem cada vez mais militantes dispostos a mudanças e a reações que se manifestavam nos sindicatos, nas alianças com outros partidos ou em outras medidas. A mudança ideológica ocorrida nos anos 50 não foi suficiente para que o "partidão" impedisse a direita de chegar ao poder. As reformas que levaram ao conhecimento dos comunistas as idéias de Antônio Gramsci permitiram um momento de alívio, um respiro mais fundo, sem, no entanto impedir a tão temida catástrofe. 
O golpe militar de 1964 surpreendeu os comunistas, que não esperavam uma reação de direita. A passividade em que se encontrou o PCB frente a esse movimento pode ser explicada pela nova política adotada, compatível com as idéias de Gramsci. A Revolução Passiva e a valorização dos meios legais e democráticos, não permitiram ao partido reagir de forma combativa aos acontecimentos daquele ano. O Partido Comunista Brasileiro, assim chamado a partir de 1962, valorizou a movimentação legal dos trabalhadores, a busca do socialismo por vias democráticas, o que significa dizer, ressaltar o valor do voto, da participação do operariado nas decisões políticas. Dessa maneira foi impossível impedir a tomada de poder pelos grupos reacionários, que ao contrário do PCB esqueceram-se do valor da palavra democracia e partiram para a ditadura.

\section{REFERÊNCIAS BIBLIOGRÁFICAS}

AGGIO, Alberto. A revolução passiva como hipótese interpretativa da história política latino-americana. In: . Gramsci: a vitalidade de um pensamento. (Org). São Paulo: Unesp, 1998. p. 161-176.

ARAÚJO, Maria Paula Nascimento. Lutas democráticas contra a ditadura. In: FERREIRA, Jorge; REIS, Daniel Aarão. (Orgs). Revolução e democracia. Rio de Janeiro: Civilização Brasileira, 2007. p. 321-354. v.3.

CARVALHO, Maria Alice Rezende de. Breve história do comunismo democrático no Brasil. In: FERREIRA, Jorge; REIS, Daniel Aarão. (Orgs). Revolução e democracia. Rio de Janeiro: Civilização Brasileira, 2007. p. 261282. v.2.

COUTINHO, Carlos Nelson. Socialismo e democracia: a atualidade de Gramsci. In: AGGIO, Alberto. (Org). Gramsci: a vitalidade de um pensamento. São Paulo: Unesp, 1998. p. 15-36.

DELROIO, Marcos. O impacto da Revolução Russa e da Internacional Comunista no Brasil. In: MORAES, João Quartim; REIS FILHO, Daniel Aarão. (Orgs). História do Marxismo no Brasil: o impacto das revoluções. 2. ed. São Paulo: Unicamp, 2003. p. 59-122. 
GONÇALVES, Leandro Pereira. Tradição e Cristianismo: o nascimento do integralismo em Juiz de Fora. In: SILVA, Giselda Brito. (Org). Estudos do integralismo no Brasil. Recife: UFRPE, 2007, p.65-96.

GRAMSCI, Antonio. Cadernos do Cárcere. Rio de Janeiro: Civilização Brasileira, 2000. v.6.

; TOGLIATTI, Palmiro. A situação italiana e as tarefas do PCI. In: NOGUEIRA, Marco Aurélio; SODRÉ, Nelson Werneck. (Orgs). Temas de ciências humanas. São Paulo: Ciências Humanas, 1980. p. 1-38.

. O legado de Antonio Gramsci. In: BOGO, Ademar. (Org). Teoria da organização política. São Paulo: Expressão Popular, 2006. p. 61-104.

JOHNSTONE, Monty. A terceira internacional. In: BOTTOMORE, Tom (Edt.). Dicionário do pensamento marxista. Rio de Janeiro: Jorge Zahar, 2001, p.197. MORAES, Dênis de; VIANA, Francisco. Prestes: lutas e autocrítcas. Petrópolis: Vozes, 1982.

NOGUEIRA, Marco Aurélio. Gramsci e os desafios de uma política democrática de esquerda. In: AGGIO, Alberto. (Org). Gramsci: a vitalidade de um pensamento. São Paulo: Unesp, 1998. p.65-102.

PANDOLFI, Dulce Chaves. A trajetória de Luiz Carlos Prestes. In: FERREIRA, Jorge; REIS, Daniel Aarão. (Orgs). Revolução e democracia. Rio de Janeiro: Civilização Brasileira, 2007. p. 221-242. v.2.

PRESTES, Luiz Carlos. O legado de Luiz Carlos Prestes. In: BOGO, Ademar. (Org). Teoria da organização política. São Paulo: Expressão Popular, 2006. p. 61-104.

SANTANA, Marco Aurélio. Bravos companheiros: a aliança comunistatrabalhista no sindicalismo brasileiro (1945-1964). In: FERREIRA, Jorge; REIS, Daniel Aarão. (Orgs). Revolução e democracia. Rio de Janeiro: Civilização Brasileira, 2007. p. 237-278.

SANTOS, João Agostinho A. Gramsci:ideologia, intelectuais orgânicos e hegemonia. In: NOGUEIRA, Marco Aurélio; SODRÉ, Nelson Werneck. (Orgs). Temas de ciências humanas. São Paulo: Ciências Humanas, 1980. p. 39-64.

SANTOS, Raimundo. Crise e pensamento moderno no PCB dos anos 50. In: MORAES, João Quartim; REIS FILHO, Daniel Aarão. (Orgs). História do Marxismo no Brasil: o impacto das revoluções. 2. ed. São Paulo: Unicamp, 2003. p. 225-258. 
A primeira renovação pecebista: reflexos do XX Congresso do PCUS no PCB (1956-1957). Belo Horizonte: Oficina de Livros, 1988.

SEGATTO, José Antônio. A presença de Gramsci na política brasileira. In: AGGIO, Alberto. (Org). Gramsci: a vitalidade de um pensamento. São Paulo: Unesp, 1998. p. 177-184.

Breve história do PCB. São Paulo: Ciências Humanas, 1981.

SILVA, Fernando Teixeira da; SANTANA, Marco Aurélio. O equilibrista e a política: o partido da classe operária (PCB) na democratização (1945-1964). In: FERREIRA, Jorge; REIS, Daniel Aarão. (Orgs). Revolução e democracia. Rio de Janeiro: Civilização Brasileira, 2007. p. 101-140. v.2.

SIMIONATTO, Ivete. O social e o político no pensamento de Gramsci. In: AGGIO, Alberto. (Org). Gramsci: a vitalidade de um pensamento. São Paulo: Unesp, 1998. p. 37-64.

SODRÉ, Nelson Werneck. Contribuição à história do PCB. In: NOGUEIRA, Marco Aurélio; SODRÉ, Nelson Werneck. (Orgs). Temas de ciências humanas. São Paulo: Ciências Humanas, 1980. p. 181-218.

VIANNA, Luiz Werneck. Caminhos e descaminhos da revolução passiva à brasileira. In: AGGIO, Alberto. (Org). Gramsci: a vitalidade de um pensamento. São Paulo: Unesp, 1998. p. 185-201.

VIANNA, Marly de Almeida G. O PCB, a ANL e as insurreições de novembro de 1935. In: FERREIRA, Jorge; DELGADO, Lucilia de Almeida Neves. (Orgs). $O$ Brasil republicano. Rio de Janeiro: Civilização Brasileira, 2003. p. 63-106. v.2.

\footnotetext{
${ }^{1}$ Especialização em Ciências Humanas: Brasil, Estado e Sociedade pela Universidade Federal de Juiz de Fora; Graduada em História pelo Centro de Ensino Superior de Juiz de Fora, e-mail: laujf@hotmail.com

2 Professor assistente do Curso de História do Centro de Ensino Superior de Juiz de Fora; Doutorando em História Social pela Pontifícia Universidade Católica de São Paulo; Mestre em Literatura Brasileira pelo Centro de Ensino Superior de Juiz de Fora; Especialista em História do Brasil pela Pontifícia Universidade Católica de Minas Gerais; Licenciado em História pelo Centro de Ensino Superior de Juiz de Fora; Participante como pesquisador dos Grupos Literatura e Autoritarismo (UFSM/CNPq); Observatório da Indústria Cultural (UFF/CNPq) e Cidadania, Trabalho e Exclusão (UFJF/CNPq). e-mail: leandropgoncalves@gmail.com

${ }^{3}$ Fundada em Moscou em março de 1919 por iniciativa dos bolcheviques, após a vitória da Revolução de Outubro na Rússia. Lenin definiu o reconhecimento da ditadura do proletariado e do poder soviético em lugar da democracia burguesa como os princípios fundamentais da Terceira Internacional. O objetivo oficial era uma união mundial das Repúblicas Socialistas Soviéticas (JOHNSTONE, Monty. A terceira internacional. In: BOTTOMORE, Tom (Edt.). Dicionário do pensamento marxista. Rio de Janeiro: Jorge Zahar, 2001, p. 197).

${ }^{4}$ Primeira revolta tenentista em que os jovens oficiais saíram em marcha até o Palácio do Catete com o objetivo de combater as tropas federais.
} 
${ }^{5}$ Lei instituída pelo Presidente Washington Luís em 1927, que censurava a imprensa e restringia o direito de reunião da população, com o objetivo expresso de restringir o movimento operário.

${ }^{6}$ Uma força comunista contra a expansão do integralismo foi montada no Brasil, uma vez que o movimento integralista teve ampla repercussão no campo político e social no Brasil na década de 1930. Iniciou suas atividades em 1932, sob a liderança de Plínio Salgado, sua organização, fortemente influenciada pelos movimentos fascistas europeus, priorizava a arregimentação de militantes e seu enquadramento em uma estrutura hierárquica e burocrática. A partir de então, logrou intenso e rápido crescimento ascendente até a decretação do Estado Novo em novembro de 1937 (GONÇALVES, Lenadro Pereira. Tradição e cristianismo: o nascimento do integralismoem Juiz de Fora. In: SILVA, Giselda Brito. (Org). Estudos do integralismo no Brasil. Recife: UFRPE, 2007, p. 65).

${ }^{7}$ Foi um dos fundadores do Partido Comunista da Itália, sendo o primeiro a tirar conclusões européias do relatório de Kruchev em 1956 e, por essa razão foi considerado como o fundador do "Euro-Comunismo".

${ }^{8}$ As idéias de Gramsci, estão organizadas nos Cadernos do Cárcere - série de anotações que ao autor italiano produziu ao longo dos anos em que esteve confinado nas prisões da Itália sob domínio do fascismo entre 1926 a 1937, de onde saiu para logo falecer.

ARTIGO RECEBIDO EM 17/03/2009. APROVADO EM 14/04/2009. 